\title{
What Did the United States Sentencing
}

\section{Commission Miss?}

\author{
Dale G. Parent $\uparrow$
}

Congress enacted the Sentencing Reform Act of $1984^{1}$ amidst great optimism that federal sentencing guidelines would both fulfill Judge Frankel's reform vision ${ }^{2}$ and build upon the states' pioneering experiences with sentencing commissions by avoiding their failures and amplifying their successes. The statute gave the U.S. Sentencing Commission (Commission) broad authority to structure sanctions, to permit judges to individualize sentences, to be parsimonious in the use of punishment, to use nonprison sentences for nonviolent first offenders, and to avoid overcrowding federal prisons.

That optimism quickly faded as the Commission began its work, and died once its guidelines were drafted. ${ }^{3}$ The Commission failed to actualize parts of its authority and ignored some elements of its own mandate. It dismissed, for various reasons, the lessons to be learned from states' experiences with guidelines systems. Critics of the Commission's work abound, particularly among federal judges, prosecutors, defenders, and legal scholars. ${ }^{4}$ Unfortunately, the brunt of those criticisms has dimmed the chances for new state guideline initiatives that could be more reasonable and effective.

This Comment argues that the processes by which sentencing guidelines are developed have important effects on both their content and viability. It highlights key differences between how the U.S. Sentencing Commission and the Minnesota Sentencing Guidelines Commission went about their appointed tasks. It concludes by discussing the prospects for redeeming the federal sentencing guidelines.

Minnesota provides an especially relevant model of sentencing reform. When the U.S. Sentencing Commission began its work, only Minnesota had

$\dagger$ From 1978 until 1982, Mr. Parent served as the first director of the Minnesota Sentencing Guidelines Commission, which was the first legislatively created sentencing commission in the nation. Mr. Parent currently works as a Senior Analyst at Abt Associates, Inc., in Cambridge, Massachusetts.

1. Pub. L. No. $98-473,98$ Stat. 1987 (1984) (codified as amended at 18 U.S.C. $\$ \S 3551-3559,3561-$ 3566, 3571-3574, 3581-3586 (1988), and 28 U.S.C. \$\$ 991-998 (1988)).

2. MARVIN E. FRANKEL, CRIMINAL SENTENCES: LAW WITHOUT ORDER (1973).

3. See U.S. SENTENCING COMM'N, FEDERAL SENTENCING GUIDELINES MANUAL (1992) [hereinafter U.S.S.G.].

4. See, e.g., Daniel J. Freed, Federal Sentencing in the Wake of Guidelines: Unacceptable Limits on the Discretion of Sentencers, 101 YALE L.J. 1681 (1992). 
operational guidelines that a legislatively created commission had developed, implemented, and evaluated. ${ }^{5}$ Furthermore, Minnesota's success in revising its sentencing system was well documented: guidelines created more uniform and proportional sentences than those of the pre-guidelines era; appellate review fine-tuned and complemented the guidelines; and nonviolent offenders became more likely to receive community sanctions as punishment, thereby averting prison crowding and disruption of court workloads. In short, Minnesota's achievements closely paralleled outcomes Congress sought at the federal level. ${ }^{6}$

The U.S. Sentencing Commission went about its work using processes that differed in many important respects from those used in Minnesota. ${ }^{7}$ It rejected Minnesota's processes because it disagreed with key values that the Minnesota commission had adopted in its guidelines. This Comment does not argue that new sentencing commissions should accept Minnesota's values: what is best for Minnesota may not be best for Texas, New York, or the federal system. New sentencing commissions should debate, select, and articulate the values they will follow in guideline development. But the U.S. Sentencing Commission's rejection of processes that proved successful in Minnesota adversely affected the structure and content of the federal guidelines.

Three principles distinguish Minnesota's guideline development from earlier, judicially developed sentencing guidelines, and from the way in which the U.S. Sentencing Commission went about its work. First, Minnesota developed its guidelines through an open process that allowed all affected organizations and individuals to participate in discussions and to influence Commission decisionmaking. This practice contrasted sharply with earlier guideline development, which had occurred in closed sessions where only judges could participate. Second, Minnesota's guidelines are openly prescriptive; they implement normative policies to guide future sentencing, organized around an underlying philosophy of "just deserts." In contrast, Minnesota's previous judicially

5. See Mannesota Sentencing Guidelines Comm'N, Minnesota Sentencing Guidelines and COMMENTARY, reprinted in MINN. STAT. ANN. § 244 app. (West Supp. 1992) [hereinafter MINNESOTA SENTENCING GUIDELINES]. Washington had only recently implemented its guidelines. See WASH. REV. CODE ANN. §§ 9.94A.010-.910 (West 1988 \& Supp. 1992). For a discussion of state analogues at the time the guidelines were drafted, see Stephen Breyer, The Federal Sentencing Guidelines and the Key Compromises upon Which They Rest, 17 HOFSTRA L. REV. 1, 3 (1988). Earlier judicially developed sentencing guidelines had been voluntary and were considered ineffective by mcst. See generally WILLIAM D. RICH ET AL., SENTENCING BY MATHEMATICS: AN EVALUATION OF THE EARLY ATTEMPTS TO DEVELOP AND IMPLEMENT SENTENCING GUIDELINES (1982).

6. See generally MINNESOTA SENTENCING GuIdelines COMM'N, THE IMPACT OF the MinNesota SENTENCING GUIDELINES: THREE YeAR EVALUATION (1984).

7. The U.S. Sentencing Commission chose a different guidelines enactment process, even though it knew of the Minnesota experience. Shortly after the federal Commission began its work, I was invited to brief its members on Minnesota's experiences. In addition, the first director of the federal Commission had previously served as research director, and later, after my resignation, as director of the Minnesota Sentencing Guidelines Commission.

8. The term "just deserts" describes retributive sentences in which the severity of punishment increases in direct proportion to the seriousness of crimes and the culpability of offenders. See ANDREW VON HIRSCH, DOING JUSTICE: THE CHOICE OF PUNISHMENTS 66-76 (1976); see also infra text accompanying notes 26-27. 
developed guidelines were descriptive, purporting to represent past practices in their structure and content. ${ }^{9}$ The descriptive guidelines suppressed or eliminated open discussions of purpose or underlying philosophy. The Minnesota Sentencing Guidelines Commission studied past practices but altered them somewhat to make future sentencing more consistent with a just deserts philosophy. ${ }^{10}$ In other words, there was no presumption that Minnesota's guidelines should simply mirror the past. In fact, key elements of Minnesota's guidelines were selected and defined to emphasize proportional punishment. Third, Minnesota's commission interpreted an imprecise statutory directive to mean that its guidelines had to work without overcrowding the state's prisons. ${ }^{11}$ Drafters of the earlier descriptive guidelines were not concerned about the impact of the guidelines on prison populations. Similarly, the U.S. Sentencing Commission ignored a congressional directive to ensure that guidelines would not overcrowd federal prisons. ${ }^{12}$

These three principles-open process, prescriptive guidelines, and recognition of prison capacity constraints-are considered below. These principles contributed to Minnesota's fruitful experience with guidelines. In contrast, the U.S. Sentencing Commission's avoidance of these principles compounded its problems with guideline development.

\section{OPEN PROCESS}

During the early stages of the process, the U.S. Sentencing Commission held numerous hearings around the country to solicit information and opinions about sentencing policy from judges, prosecutors, defenders, and interested members of the public. The Commission's later decisionmaking process, however, was closed to external scrutiny and input. On the other hand, Minnesota's Commission used an open process of guideline development, one that allowed all organizations and interested individuals to participate in the Commission's deliberations and to influence its decisions.

Minnesota's commission viewed guideline development as a political task, one of formulating public policy to guide officials who sanctioned convicted criminals. The creation of a guidelines commission merely shifted the politics of sentencing reform from the legislature to a commission. Its members had to debate and agree on lofty, and sometimes conflicting, values, including the

9. See infra text accompanying note 18 .

10. The Minnesota commission did not want to radically alter the system by prescribing future practices that radically differed from those of the past. Rather, it made modest changes at the margins to shift practices toward a just deserts philosophy. Under Minnesota's guidelines system, almost $95 \%$ of convicted felons receive a sentence of prison or probation that is approximately equal to the sentence they would have received under past practice. Only about five percent of sentences differ from pre-guidelines norms.

11. The enabling legislation directed the Commission to give substantial consideration to available correctional resources, including, but not limited to, the capacities of prisons and jails. MNN. STAT. ANN. $\$ 244.09$, subd. $5(2)$ (West Supp. 1992).

12. 28 U.S.C. $\$ 994(e)(1988)$. 
purposes of sentencing and the proper balance between society's demand for punishment and accused offenders' rights to a fair sentence.

Minnesota's commission also had to face political realities: the guidelines would be stillborn if a majority of legislators opposed them. The commission simultaneously had to identify and nurture its supporters and convert or neutralize its critics. To do so, it needed to know who the players were and where they stood on various issues. It needed a forum in which it could both receive and convey information. The commission therefore invited all affected interests and organizations to come before it to be heard and to participate in guideline development.

The commission's commitment to public participation went beyond the requirements of Minnesota's Open Meeting Law, ${ }^{13}$ which mandates that all discussion and decisionmaking in government agencies occur in public meetings, whose times, dates, and agendas are published in advance. For example, the commission developed an extensive mailing list of interested organizations and individuals and sent meeting notices directly to them.

The chairperson, Jan Ingrid Smaby, asked groups unrepresented on the commission-for example, law enforcement organizations-to designate a person to attend commission meetings and to act as a liaison between the commission and the organization. She made similar provisions for groups that were technically represented but whose needs and interests were not clearly focused. For example, although one member of the commission was a public defender, he could not represent the complete range of the defense bar's views. Unlike county attorneys, who form a well organized and effective lobby, Minnesota's public defenders are a fragmented and diverse group, and as a group their positions tend to be less clearly defined. Consequently, Ms. Smaby asked public defenders in larger counties to attend meetings regularly. Ms. Smaby also tried to account for groups that, although technically represented on the commission, maintained disagreements with their chosen representative. ${ }^{14}$

The commission held most of its meetings in the Minneapolis-St. Paul metropolitan area, in easily accessible central locations. The commission also held a series of meetings around the state so that officials and citizens in outlying areas would have access to the commission.

13. MinN. STAT. ANN. § 471.705 (West 1977).

14. This situation occurred in the Minnesota Department of Corrections (DOC). Although the commissioner of the DOC was also a member of the Sentencing Guidelines Commission, County Corrections Department officials often felt that the DOC commissioner did not adequately represent their interests. Although the commissioner administered the Community Corrections Act (CCA) subsidies to counties, MINN. STAT. ANN. $\$ 401$ (West 1977), he also ran the state prison system, which consumed most of the DOC's funding. Based on their experiences in the 1970's, CCA counties feared that the DOC would support prisons and pare the CCA in its budget requests. DOC and CCA interests also conflicted on countless administrative issues important to participating counties. Hence, the Sentencing Commission chairperson convinced several of the larger county corrections departments to send representatives to the commission's meetings on a regular basis. 
Ms. Smaby conducted meetings in an informal and collaborative way, permitting and encouraging members of the audience to participate freely in the commission's discussions and debates. If deep divisions surfaced on important issues, she often extended discussion or postponed decisions until all persons wanting to comment had the chance to do so, or until a consensus emerged around an identifiable position.

The open process had several important effects. First, no one could claim that he or she had been denied the chance to influence the content and development of the guidelines. No single group prevailed on all issues; rather, everybody admitted that they had been treated fairly and acknowledged that the Commission had heard and weighed their arguments and positions before making any decisions.

Second, the open process reduced pressure on commission members to act as vigorous interest group advocates and permitted them, especially on a limited number of critical issues, to decide what was best for the system as a whole. For example, the public defender on the commission was not the only person representing the interests of the defense bar, just as the county attorney on the commission was not the only prosecutor present to voice prosecutorial interests. Members adopted less rigid positions and employed less strident rhetoric than they might otherwise have done if they had been the only advocates for their constituents' interests. On virtually all tough issues, some of which could have unraveled the entire effort, commission votes were unanimous.

Third, the open process educated those in attendance. Prosecutors heard a full discussion of competing values and positions advocated by defenders and probation officers. Those who attended regularly, a stable cadre of about thirty participants, slowly came to accept the unwritten ground rule underlying the process: the commission would try to reach tactical accommodations around which a consensus could emerge, but it would not abandon the broader values, such as achieving more proportional punishment, that lent coherence to the overall effort.

Fourth, the open process had important effects on the form and content of the guidelines. It became clear, for example, that the guidelines had to be simple and have "face validity." The commission's quest for simplicity and face validity affected the way it wrote major sections of the guidelines.

The Minnesota sentencing guidelines have "face validity" for two reasons: they are based on factors that most people consider critical in sentencing, and they organize and present information in a way that is immediately illuminating. The guidelines' essential features are displayed on a single page (a sentencing grid) that presents the two major dimensions of offense seriousness and prior record and shows how each affects decisions about imprisonment and sentence length. ${ }^{15}$ While the guidelines in toto contain a great deal of more detailed

15. See MinNesota SENTENCING GUIDELINES, supra note 5 , at 413 (reprinting grid). 
information, capturing the essential information on a single page makes sentencing policies concrete and understandable. ${ }^{16}$ Face validity made it much easier to build political support for the guidelines.

The quest for simplicity affected many decisions about specific guideline policies. When developing a procedure for scoring offenders' prior criminal records, the commission sought to draft rules that would be easy to apply, that could be implemented by officials confronted with imperfect information systems, and that would work well for the great majority of cases.

In contrast to the Minnesota Sentencing Guidelines Commission, the U.S. Sentencing Commission framed its guidelines through a closed process and adopted official rules of procedure. ${ }^{17}$ The decision to insulate the guidelines from outside input had a considerable negative impact on their substantive content.

\section{PRESCRIPTIVE GUIDELINES}

The U.S. Sentencing Commission did not attempt to develop descriptive guidelines, but neither did it develop prescriptive guidelines. It did not articulate the purposes that ought to govern future sentencing, and as a result, it could not structure its guidelines to achieve particular results. From a value-centered viewpoint, then, the U.S. Sentencing Guidelines are adrift. By contrast, the Minnesota Sentencing Guidelines Commission selected punishment, implemented under a "just deserts" framework as the guidelines' primary purpose.

Other sentencing commissions could, with justification, select a different guiding purpose; Minnesota's choice may not be the best for all. But asserting a purpose imparted a coherence to Minnesota's guidelines that prior efforts had lacked, and that helped the commission to see components of the guidelines as part of an integrated whole.

Before Minnesota's efforts began in 1978, sentencing guideline experience was limited to groups of judges developing guidelines that were descriptive and voluntary. ${ }^{18}$ Under this approach, researchers analyzed data from past sentenc-

16. To be sure, the guidelines required a great deal more information than the grid to make them work. This information included detailed offense seriousness scales cross-referenced by statutory citations, several pages of guidelines and commentary on computing criminal history scores, and several pages of rules for special circumstances, such as consecutive sentencing. Nonetheless, Minnesota's original guidelines and commentary were less than 40 pages long.

17. While the federal sentencing guidelines were being adopted, I had several conversations with staffers at the U.S. Sentencing Commission. These conversations confirmed my general impression that the commission did not employ an open process.

18. Judges were not compelled to follow these guidelines or to report their reasons for ignoring them. The judicial guidelines' advocates only hoped to curb extreme variations by bringing "outliers" closer to the mean. Evaluations of such voluntary guidelines, however, found that compliance rates were seldom high enough to reduce sentencing disparity significantly. In addition, descriptive guidelines often contained wide ranges of punishments (e.g., 25 to 60 months), so that compliance with the guidelines would merely perpetuate the variation observed in the empirical research. By contrast, Minnesota's guidelines used narrower ranges (e.g., 42 to 46 months), so that compliance with the guidelines would reduce the range of 
ing practices and developed empirical models that purported to explain these practices. Judges used these descriptive models as benchmarks around which to develop guidelines. The resulting guidelines were voluntary. Judges were not compelled to consult them when sentencing, and if they gave a sentence that differed from the applicable guideline, they were not obliged to give reasons. Descriptive and voluntary guidelines did not create or enlarge the right to appeal the sentence.

Of course, completely descriptive guidelines would incorporate both good and bad dimensions of past sentencing. To prevent the codification of bad practices, judges were supposed to conduct a limited prescriptive review to remove any elements they found offensive or inappropriate. In practice, however, judges approached this limited prescriptive review with trepidation. Altering past practice meant making policy, a responsibility many judges were reluctant to assume. Judges also lacked the education and training necessary to assess or challenge empirical models developed by social scientists, and tended to accept their results as correct, even if the empirical analysis explained relatively little of the variation in sentencing. As a result, judicially developed guidelines remained starkly descriptive.

At the time the Minnesota Sentencing Guidelines Commission began its work, criticism of the descriptive model emerged from a small group of scholars. ${ }^{19}$ They argued that sentencing commissions should prescribe values to guide future sentencing and structure their guidelines to achieve those values in practice. ${ }^{20}$

Several factors supported the development of prescriptive guidelines in Minnesota. First, the commission was developing guidelines for an entire state, whereas the descriptive guidelines had previously been applied mainly in large

variation in sentencing. See DON GOTTEREDSON ET AL., GUIDELINES FOR PAROLE AND SENTENCING: A POLICY CONTROL METHOD (1978); LESLIE WILKINS ET AL., SENTENCING GUIDELINES: STRUCTURING JUDICIAL DISCRETION (1978).

19. See, e.g., John C. Coffee, Jr., The Repressed Issues of Sentencing: Accountability, Predictability, and Equality in the Era of the Sentencing Commission, 66 GEO. L.J. 975 (1978); Richard Singer, In Favor of Presumptive Sentences Set by a Sentencing Commission, 5 CRIM. JUST. Q. 88 (1977).

20. For example, John Coffee argued that a prescriptively oriented sentencing commission would, for the first time, define a microlevel public policy of sentencing, a level at which issues of faimess were traditionally ill-defined. See Coffee, supra note 19, at 1043. In the past, judges routinely considered offenders' current and past employment when sentencing, but each judge used different indicators and gave them variable weight. Coffee thought that sentencing commissions should decide whether to consider employment at all, and if so, how to measure employment and how much weight to give it in sentencing decisions, creating a uniform standard for all courts to apply. Id.

Whether courts should consider employment in calculating sentences depends, in tum, on the purposes that guide sentencing. If the primary purpose is either to punish or deter, then the employment status and history of offenders is largely irrelevant. However, if the primary purpose is either to rehabilitate or incapacitate prisoners, then information on offenders' employment histories might be much more relevant to sentencing decisions. Data might show, for example, that offenders who are unemployed when they commit their crimes, or who have long histories of unemployment, are more likely to commit new crimes in the future. 
metropolitan courts. ${ }^{21}$ Because sentencing patterns in different regions might have differed widely, a statistical average might not have accurately described sentencing practices in any particular location. Statewide guidelines thus needed a prescriptive framework. Second, the commission's legislative mandate gave it authority to make policy. The judges who developed descriptive guidelines did not have such clear legitimacy and were reluctant to assume it. Third, the commission derived legitimate prescriptive power from the fact that it was a representative body. Two authorities, the Governor and the chief justice of the state supreme court, had chosen its members. The commissioners' mission was to portray the interests of their respective constituents, while collectively providing a balanced and systemwide perspective on guideline development. ${ }^{22}$ Descriptive guidelines characteristically received only judicial input.

Early in its deliberations, the Minnesota commission considered developing guidelines that encompassed different purposes, without setting priorities among them. Later, however, members arrived at a unifying purpose, almost by a process of elimination. The commission determined that the guidelines should not be based on incapacitation of the offender. In part, this was a practical concession: the commission wanted guideline development to be informed by data about current sentencing patterns. In order to incapacitate high-risk offenders, the guidelines would have to predict which groups of offenders were more or less likely to commit future crimes. The commission could not use data on current sentencing to predict offenders' future behavior. To predict future crime, the commission would have had to collect data on the offenses, criminal histories, and personal characteristics of offenders sentenced several years earlier and then record their statuses (success or recidivism) after returning to the community. Such a study would have been expensive and time consuming, and the commission could not have afforded two separate, large-scale data collection efforts: one to describe current practice and another to predict offender outcomes.

The commission also displayed little interest in general deterrence. While it seems likely that more crime would exist if offenders were not punished, the commission found no compelling evidence to suggest that punishing selected offenders more severely would lower crime rates. At the time, rehabilitation was in disfavor as a sentencing goal. ${ }^{23}$ The determinate sentencing move-

21. See generally ALFRED BLUMSTEIN ET AL,, RESEARCH ON SENTENCING: THE SEARCH FOR REFORM 138-39 (1983) (discussing descriptive sentencing guidelines in Denver, Chicago, Newark, and several other cities).

22. The enabling legislation specified that the Commissioner of Corrections would serve on the Sentencing Guidelines Commission. It directed the Governar to select a defense attomey from a list submitted by the Minnesota Public Defender and a county prosecutor from a list submitted by the County Attomeys Association. The chief justice (or his designee) was a member, and the chief justice selected two trial judges to serve. The Governor had a free hand in selecting only the two citizen members. MINN. STAT. ANN. $\& 244$ (West Supp. 1992).

23. In fact, widespread criticism of the rehabilitative model of penology emerged in the 1970's. For a general discussion, see BLUMSTEN ET AL., supra note 21, at 64 . 
ment $^{24}$ received much of its support, both nationally and in Minnesota, from policymakers who believed that coercive treatment did not work. ${ }^{25}$ Eventually, the Minnesota Sentencing Guidelines Commission settled on punishment as the unifying purpose around which to develop its guidelines. "Just deserts"26 served as the framework within which the commission pursued its goal of punishment.

The principle of just deserts requires punishment to be administered in proportion to the gravity of the offense and the culpability of the offender. The harm done determines the gravity of the offense. The offender's intent and her prior record determine culpability (although some theorists reject consideration of prior record, arguing that intent alone determines culpability) ${ }^{27}$ Once the commission selected punishment as a unifying purpose, the crime itself became the primary factor in determining sentence severity because the Minnesota criminal code defines crimes in terms of harm done and offender intent. An offender's criminal record played only a secondary and modifying role; it merely provided an additional measurement of culpability. Articulating punishment as the primary purpose clarified the two main dimensions of the guidelines-the seriousness of the offense and the offender's prior record-and the relative weight assigned to each.

The commission then decided that in grading offense seriousness, the guidelines would examine convictions, not alleged offenses. ${ }^{28}$ It reasoned that if charges were filed but dropped, or if a defendant asserted her innocence to charges on which she was never convicted, information about those alleged crimes should not be used to assess the seriousness of the offense of conviction. ${ }^{29}$ If the commission had used alleged behavior to assess offense serious-

24. For determinate sentencing arguments, see FRANKEL, supra note 2; vON HIRSCH, supra note 8. A sentence is determinate if the offender knows, on the date of sentencing, how long he will be confined under the sentence. A sentence is indeterminate if, after the sentencing, an authority other than the judge makes decisions about the duration of confinement.

25. Treatment was the primary purpose of indeterminate sentencing. For a general discussion of indeterminate sentencing, see NORVAL MORRIS \& MICHAEL TONRY, BETWEEN PRISON AND PROBATION: INTERMEDIATE PUNISHMENTS IN A RATIONAL SENTENCING SYSTEM 20-24 (1990). In theory, the parole board would release an offender at the time it determined the offender had been rehabilitated. Because the parole board controlled prison releases, critics argued that offenders were coerced into participating in treatment in order to shorten their prison terms. Id. at 24 ("[F]rom a psychological perspective, it defies common experience to imagine that coerced participation in treatment programs will often facilitate personal growth and change ... [c]oupling participation in treatment programs with a likelihood of earlier release motivated prisoners to participate, but often it did not motivate them to change.")

26. See vON HIRSCH, supra note 8 , at 66-76.

27. See Singer, supra note 19.

28. The commission was troubled by the prospect of sentencing defendants on the basis of crimes for which they had not been charged, for which charges were dropped, or even for which they had been found innocent at trial.

29. The commission was aware of the argument that alleged offense sentencing was necessary to allow judges to offset the increased prosecutorial control that would arise under a sentencing guidelines system. The guidelines enhance the significance of charging practices. The commission responded that, under guidelines, prosecutors would exercise their charging discretion with greater responsibility only if the benefits of the bargains they offered were real and not illusory. As long as the sentencing judge could withdraw the benefit, prosecutors would be encouraged to play fast and loose with charging. For a thorough discussion 
ness, prosecutors could offer irresistibly lucrative plea bargains, only to move to have the illusory benefits retracted at sentencing. By opting for conviction offense sentencing, the Minnesota commission avoided forcing courts to gather additional facts about uncharged or unproven conduct when scoring offense seriousness, or to grapple with other difficult issues like determining which evidentiary standards or burdens of proof should govern. In contrast, the U.S. Sentencing Commission embraced alleged offense sentencing, thereby greatly increasing the scope and complexity of the information required to determine offense seriousness. ${ }^{30}$

Minnesota's commission, therefore, found all the information it needed to make approximate judgments about offense seriousness in the statutes defining crimes. ${ }^{31}$ The conviction offense determines the offense seriousness level, and Minnesota's felony statutes enumerate the elements of the offense that must be proved or the elements to which a defendant has to plead guilty. In addition, where relevant, Minnesota's criminal code defines separate crimes in which intent, but not outcome, varies. For example, manslaughter is subdivided into different statutes, distinguished only by variations in the offender's intent. ${ }^{32}$ For virtually all crimes, officials applying the sentencing guidelines need to know only the statutory citation for the conviction offense to determine accurately the guideline's offense seriousness level.

Minnesota's commission divided all felonies (except first-degree murder, which was excluded from the guidelines by $\mathrm{law}^{33}$ ) into ten offense seriousness levels. Within each level, the commission deemed all felonies to be roughly comparable in seriousness and recommended the same punishment for offenders with similar prior records. The commission determined that, unless there was something extremely unusual about a case, the guidelines' sanctions should hold.

However, the commission recognized that a few cases would contain "substantial and compelling" elements justifying departure from the guidelines. ${ }^{34}$ It permitted judges to use such departures to fine-tune proportionality in punishment or to assert some goal other than punishment as paramount for

of the advantages and disadvantages of alleged or "real" offense sentencing, see Michael $\mathrm{H}$. Tonry, Real Offense Sentencing: The Model Sentencing and Corrections Act, 72 J. CRMM. L. \& CRIMINOLOGY 1550 (1981).

30. See U.S.S.G., supra note 3, ch. 1, pt. A, intro. 4(a) (expressing Commission's shift from pure "real offense" system to mixed system of "real" and "charge offense" sentencing); cf. Breyer, supra note 5, at 11 (noting commission made "compromise" between "real" and "charge" offense system).

31. In four offense categories - theft, theft-related, forgery, and forgery-related crimes-the commission also believed that the amount of loss was relevant to determining offense severity. Hence, to improve offense seriousness gradations, it subdivided each of these four types of crimes into two categories: those involving losses of more than $\$ 2,500$ and those involving losses of less than $\$ 2,500$. MINNESOTA SENTENCWNG GUDELINES, supra note 5 , at 413-20.

32. See MinN. STAT. ANN. $\$ \S 609.20-.205$ (West Supp. 1992).

33. See MinN. STAT. ANN. $\$ 609.185$ (West Supp. 1992); MINNESOTA SENTENCING Guidelines, supra note 5 , at 413 .

34. MinNesota SENTENCING GUIDElines, supra note 5, at 402. 
the particular case. The goal of punishment also helped the Minnesota commission define some of the aggravating or mitigating factors that could justify departures. For example, departure might be appropriate if a property crime involved an especially large loss, multiple victims, repeated victimization over an extended period of time, or unusually sophisticated planning. ${ }^{35}$

While the commission selected punishment as the primary and unifying purpose, other criminal justice officials and political actors found that the completed guidelines furthered their own, quite different, purposes. For example, sheriffs and police strongly supported a general deterrence policy. While the commission explicitly rejected this goal, the guidelines increased the certainty of punishment for violent criminals, drug dealers, and habitual property offenders, and increased the severity of punishment for offenders with long criminal histories. These were the types of crimes and criminals that the police most wanted to deter. To deterrence advocates, the guidelines looked like an improvement.

Likewise, those who wanted to incapacitate high-risk offenders also saw advantages to the guidelines. Under the guidelines, both the frequency and duration of imprisonment increase with the length of offenders' criminal histories. Because past criminal behavior is considered to be the best predictor of future criminal behavior, the guidelines have probably had a discernible, albeit small, incapacitation effect: those with higher criminal history scores, who generally have a greater probability of recidivism than those with low scores, are kept off the streets for longer terms. ${ }^{36}$

In all of their presentations, commission members and staff stressed that the guidelines were developed to punish, not to incapacitate or deter. The commission emphasized that the guidelines' punishment objective was nonutilitarian: it did not expect the guidelines to affect either overall crime rates or individual felons' future behavior. Nonetheless, the commission needed broad support among criminal justice organizations when the guidelines were submitted for legislative review. If, despite its clear disclaimers, others saw their own values reflected (even dimly) in the guidelines, the commission welcomed their support.

35. See id. at 403-04.

36. Had the commission decided to develop incapacitation-based guidelines (a choice it considered and ultimately rejected), it would have employed an entirely different method. To accomplish such a task, a sentencing judge would have to collect data on offender and offense characteristics for persons sentenced six or seven years earlier. It would then follow those persons for a uniform period of approximately two or three years after their release from confinement (if any), and collect data on their behavior to measure recidivism during the followup period. Such a study would also have to analyze these results to identify the relation of offender or offense factors related to outcomes, and to develop a prediction device that would have to be validated on a sample of comparable offenders. The prediction device would probably need revision and reevaluation on a regular basis. 


\section{RECOGNITION OF PRISON CAPACITY CONSTRAintS}

The Sentencing Reform Act directed the U.S. Sentencing Commission to minimize the possibility of crowding in the federal prisons when drafting the sentencing guidelines. ${ }^{37}$ The Commission ignored this congressional directive and developed its guidelines without concern for their effects on prison populations.

The Minnesota Sentencing Guidelines Commission decided that its guidelines should not cause prison populations to exceed ninety-five percent of capacity. ${ }^{38}$ At the time of this decision, Minnesota's prison population was at ninety-eight percent of capacity and rising. The use of prison capacity as a constraint in guideline development was unprecedented. For the first time, effective coordination of sentencing, correctional, and fiscal policies took place.

Several factors enabled the commission to adopt this position. During the 1970's Minnesota had enacted the Community Corrections Act (CCA), ${ }^{39}$ which established a legislative policy of nonimprisonment sanctions for property offenders and gave counties financial incentives to develop additional community-based sanctions and services. The legislature enacted the CCA, in part, to limit the prison population and to avoid the large capital costs of new prison construction.

In 1977, the Minnesota Department of Corrections (DOC) persuaded a reluctant legislature to appropriate twenty-three million dollars to build a new high-security prison. Just one year later, the DOC informed the legislature that its original cost estimates had been incorrect, and it would need an additional ten million dollars to complete the facility. Many legislators accused the DOC of "low-balling" the first estimate to lure supporters and force the legislature to pay the balance later. In truth, the DOC simply erred badly in its cost estimates. In any case, in 1978 the legislature made it very clear that it did not intend to build more prisons in the near future.

Between 1976 and 1978, reform advocates carefully drafted sentencing bills that would avoid increasing Minnesota's prison population. They chose this "zero-impact" strategy in order to garner political support from diverse groups that opposed increased spending for prisons. These groups included advocates of community corrections who thought that expanded prison funding threatened $\mathrm{CCA}$ subsidies, ${ }^{40}$ and fiscal conservatives who generally wanted less spending and who particularly opposed large capital outlays, whether for new prisons, hospitals, or schools. If a proposed sentencing reform bill would cause the

37. 28 U.S.C. § 994(g) (1988).

38. The Commissioner of Corrections, also a member of the Sentencing Guidelines Commission, emphasized that prisons need a cushion between population and capacity to provide flexibility in classification and placement, and to allow officials to repair and maintain the physical plant. Hence, he argued for a constraint on prison population at less than $100 \%$ of capacity.

39. MNN. STAT. ANN. § 401 (West 1977); see also supra note 14.

40. See supra note 14. 
prison population to exceed capacity, advocates of the bill had to introduce other amendments to offset the prison population increases.

In the long term, two factors determine prison populations: the number of offenders admitted and the length of their stays. Guidelines can set policies that control both factors, and therefore they can set and maintain prison populations at any level deemed acceptable. ${ }^{41}$

Not everyone thought the commission made the correct decision. Judges, prosecutors, and police were critical and sometimes derisive of the capacity constraint concept. When commission staff described capacity constraint to a statewide judicial conference, one judge suggested that the daily prison populations should be broadcast each morning along with the livestock reports, so that judges would know if there was room for newly convicted offenders to go to prison that day. ${ }^{42}$

The commission spent a lot of time justifying its position. Members did not hold press conferences, but they did discuss the guidelines informally with criminal justice organizations and civic groups, in radio talk shows, and at church coffee hours. Commission members and staff attended over one hundred such gatherings during the year the guidelines were developed. They stressed the following points:

- The state had an overriding obligation to avoid subjecting incarcerated citizens to unconstitutional conditions of confinement.

- Only the legislature-not the commission-could decide how many prison beds the state should provide because only the legislature could allocate the limited public funds, whether for prisons, education, highways, or health care.

- The commission's proper role was to recommend the most reasonable use of available prison capacity to the legislature. If the legislature wanted to change policies affecting sentencing (e.g., definitions of crimes, mandatory confinement, changed durations of confinement), the commission could estimate the impact of policy changes on correctional resource needs. Armed with that information, the legislature could then make a more informed decision about where to spend limited public revenues.

41. Of course, something other than current capacity could be the parameter. Andrew von Hirsch, who advised the Minnesota commission during its deliberations, argued that Minnesota's use of existing capacity was acceptable only because the state had a history of low imprisonment rates. Von Hirsch argued that other states should explicitly determine a prison capacity level. Conceivably, states could draft guidelines that reduced prison populations. In practice, however, the trend has been the opposite. Both Washington and Oregon developed guidelines constrained not by existing capacity, but by future prison capacities that would result from expansion programs already funded by their respective legislatures. See, e.g., WASH. REV. CODE ANN. \$ 9.94A.040(6)-(7) (West 1988); Kathleen M. Bogan, Constructing Felony Sentencing Guidelines in an Already Crowded State: Oregon Breaks New Ground, 36 CRIME \& DELINQ. 467, 468 (1990).

42. See Dale G. PARENT, STRUCTURING CRIMnAL SENTENCES: THE EVolution OF MINNESOTA'S SENTENCDNG GUIDELDES 42 (1988). 
- Decisions rendered by independent officials, each acting without a microlevel sentencing policy, had resulted in widespread prison crowding in other jurisdictions. Thus, "blame" for crowding was diffused across the entire criminal justice system. Under guidelines, however, crowding would be a conscious policy choice; the commission and the legislature would share responsibility, because they could choose to avoid crowding. A conscious policy decision to crowd prisons would be more vulnerable to constitutional challenge.

- Crowding endangered the guidelines. Some judges, prosecutors, and defense attorneys would circumvent the guidelines to avoid crowding. If the commission did not cleal with crowding in the first instance, but later changed the guidelines to counteract this problem, its amendments would be vulnerable to political attack. Under Minnesota's formulation of presumptive sentencing, parole release had been abolished, leaving no safety valve to deal with crowded prisons.

In order to ensure that its guideline policies would not overcrowd its prisons, Minnesota had to find new and improved ways to estimate future prison populations. The commission developed computer models to simulate the effects of different options for guideline policies. ${ }^{43}$ Staff members could give the commission almost immediate feedback on what a particular option would "cost" or "save" in terms of prison beds. If the simulation showed that an option selected in one guideline policy would push population above capacity, the commission would need to select options in later policies that reduced the prison population by an equal amount.

It is important to emphasize that the limits of prison capacity did not drive the selection of guideline policies. In every instance, basic policies were chosen for other reasons, usually to advance the goal of proportional and just punishment. However, the commission tested all the policies for prison population impact and fine-tuned many of them to stay within the capacity limits.

The capacity constraint had important effects on commission decisionmaking. All members, as well as nonmembers regularly attending the meetings, eventually came to view their task as one of distributing punishment under conditions of scarcity. Imprisonment was not a free public good whose use was to be maximized; rather, it was a scarce and expensive resource, which had to be allocated rationally. The commission faced a zero-sum situation when it drafted the guidelines because Minnesota's prisons were virtually full. If one

43. The commission received a $\$ 12,500$ grant from the National Institute of Corrections and an equal amount of state funds to develop a prison population impact simulation model. This model provides quick and accurate estimates of how different policies under consideration will affect the number and composition of the prison population over a five-year period. For a complete description of the model, see KAY A. KNAPP \& RONALD E. ANDERSON, MINNESOTA SENTENCING GUIDELINES COMM'N, MINNESOTA SENTENCING GUIDELINES POPULATION PROJECTION PROGRAM USER'S MANUAL (1981). 
group of offenders received incarceration in lieu of probation or longer prison terms than in the past, another group would correspondingly receive probation rather than incarceration or shorter prison terms than in the past.

The capacity constraint was a catalyst for compromise among commission members whose constituents' interests conflicted. The commission's prosecutor might prevail on an option that would punish some felons more severely and cause future prison crowding, but he would then have to concede some other option favored by the defense attorneys that would bring the projected prison populations back below the capacity limit. This further forestalled the emergence of rigid interest group advocacy among commission members and promoted a work ethos stressing tactical accommodation within the framework of consistent strategic principles.

The capacity constraint disciplined the commission in its allocation of punishment. Neither individual members nor the commission as a whole could pander to the public or to a particular constituency by advocating harsher punishments across the board. Some offense categories could receive harsher punishments, but other categories would receive lighter ones in order to stay within capacity limits: tradeoffs were essential. In making those hard choices concerning the categories of offenders that were most deserving of punishment, the commission had to make decisions that it could justify publicly.

The capacity constraint, together with the ability to analyze the population impact of policy options, shielded the commission from political pressure to toughen sentences for selected offenders during the final guideline drafting. In the last month before the commission sent the guidelines to the legislature, prosecutors, victims' rights advocates, and police groups vigorously lobbied the commission to make sentences more severe for their particular "favorite" crimes. ${ }^{44}$ These collective changes would have pushed prison populations dramatically above capacity, and would have undermined the proportionality embodied in the guidelines' penalty structure. Armed with evidence of the population effects of these revisions, the commission resisted sweeping changes. ${ }^{45}$

After the guidelines went into effect, the legislature began asking the commission for "prison population impact statements" on all bills that affected sentencing. These statements allowed the legislature to make more informed judgments; if they favored a bill that would drive up prison populations, they now knew more precisely what it would cost and could then make tough but

44. At the time, the price of silver had risen sharply, and Minnesota was plagued with a steep increase in residential burglaries. Police, therefore, advocated far tougher sanctions for residential burglaries. Simultaneously, advocates for sexual assault victims urged the commission to raise penalties for those convicted of certain criminal sexual conduct offenses.

45. The commission did make several minor adjustments during this period on matters raised by these advocate groups. These changes generally enhanced the rationality of offense seriousness rankings or improved the proportionality of punishments. 
informed decisions about whether to enact the bill, and, if so, where to find the money.

\section{Closing Thoughts}

If the U.S. Sentencing Commission had followed a rational process of guideline development-by stating its purposes, by acknowledging constraints within which the guidelines had to function, and by opening its information flow and decisionmaking processes - it is unlikely that its guidelines would have strayed so very far from past practice or that they would have been so complex and rigid. But the federal Commission took an ideological, even political, approach to guideline development that disavowed constraints, suppressed discussions of purpose, closed decisionmaking to interested and affected parties, and departed substantially from past sentencing norms.

Even under the best conditions, presumptive sentencing guidelines are unlikely to win judicial popularity contests. If one had polled Minnesota's judges during the early years of guideline implementation, most of them probably would have decried the sudden and strict bounds placed on their previously unfettered discretion. Yet at the same time, most probably would have agreed that Minnesota's guidelines had generally produced appropriate sentences.

Some judicial criticism may be transitional: it takes time for judges to adapt to a fundamentally new regime. While all cases are different, not all cases are different in ways that ought to matter when applying a microlevel public policy of sentencing. Unwarranted disparity occurs not only when judges fail to distinguish one case from others, but also when the reasons for their distinctions run contrary to the microlevel public policy of sentencing. The test of success is not whether judges are happy, but whether reasonable policymakers and practitioners agree that the criteria used to classify offenders and offenses are appropriate, and that the penalty structure is fair. The strength, breadth, and persistence of judicial criticism levied against the federal guidelines points to the core problem: judges reject the guidelines as appropriate norms to govern federal sentencing. Judges believe that the guidelines are too severe and that they shift sentencing outcomes too far from preexisting patterns. Because they so often disagree with the guidelines' outcomes, many judges want more flexibility to depart from them. ${ }^{46}$

If most federal judges thought that the guidelines furthered appropriate norms, they would find less need to depart from them, and their complaints about inflexibility would diminish. In order for that to happen, however, the guidelines need fundamental revision, not fine-tuning. The critical question is this: can these fundamental revisions take place years after the federal guide-

46. Cf. Freed, supra note 4, at 1685-86 n.10 (citing judicial attacks on federal sentencing guidelines). 
lines have been implemented and integrated into the federal criminal justice system? This closing section considers different ways in which the federal sentencing guidelines might be changed and the prospects for their approval.

The most appropriate ways to change flawed guideline policies are through existing channels of policymaking: the commission's power to revise the guidelines or the congressional power to reconstitute or abolish the commission.

\section{A. Commission Revision of Its Guidelines .}

The U.S. Sentencing Commission could itself, at any time it chooses, fundamentally revise its guidelines. Fundamental changes in the guidelines would mean fundamental changes in the values the commission has endorsed, embodied in the guidelines, and defended against critics. A skeptic could easily conclude that it is unrealistic to expect the existing commission-wedded as it is to an ideological approach to guideline development-to suddenly adopt a rational approach to guideline revision.

\section{B. Congressional Revision of Federal Sentencing Guidelines}

Congress could create a new independent sentencing commission and direct it to revise the work of its predecessor. This would provide a new chance to learn from the successes and failures of prior federal and state sentencing commissions. If Congress were to pursue this option, the new commission should:

1. have its members nominated by a variety of interest groups and appointed by a variety of authorities, for a better balance of viewpoints;

2. consist of trial judges, federal prosecutors and defenders, federal probation and prison officials, and members of the public;

3. articulate a purpose or purposes to guide future sentencing;

4. operate in the open; and

5. develop capacity-constrained guidelines.

\section{Congressional Enactment of a New Sentencing Reform Model}

Congress could abort the current sentencing guidelines and seek a new model of reform. The impetus for uniformity and consistency in federal sentencing, however, is probably too strong to permit a return to the status quo ex ante. In the alternative, Congress could seriously reconsider an option proposed and 
rejected when it drafted the Sentencing Reform Act: a dual guideline system. ${ }^{47}$ Under a dual guideline model, judges would use one set of guidelines to make sentencing decisions, while a parole board or board of prison terms would use another to make releasing decisions for those imprisoned. A single body could develop both sets of guidelines, thus promoting greater consistency between them, or separate agencies could be authorized to develop each. In either case, the administrative agencies should adhere to fundamental policies specified by Congress and be subject to strict congressional oversight.

Federal judges would use the sentencing guidelines to determine which offenders should or should not be imprisoned, while the parole board would rely on guidelines to set punitive conditions of probation. A parole board or board of prison terms would rely on separate guidelines to determine the duration of imprisonment and conditions of postprison supervision. Durations set by a parole board or board of prison terms could be adjusted later only for limited exceptional reasons. In addition, the board of prison terms could be charged with making retroactive adjustments in prison terms for those sentenced under prior regimes.

In reality, the prospects are bleak for either type of congressional action to reform federal sentencing. It took Congress a decade to enact the Sentencing Reform Act. Building congressional support for a major guideline revision or for enactment of new reform models -would be a slow and difficult process. Congressional leaders who championed sentencing reform in the 1970's and early 1980's have moved on to other issues. The Commission's initial guidelines have sharply altered the exercise of discretion and have shifted the balance of interests in sentencing. Those who think their authority or latitude will suffer from major guideline revision or new reform models will vigorously resist them. Any recommendation to make even some sentences less severe would be vulnerable to attack as being "soft on crime."

Congress has not recognized its altered role in defining sentencing policy under presumptive guidelines, and until it does, any congressionally mandated revision will be imperiled. The Sentencing Reform Act signaled a transition from symbolic to real sentencing; yet after 1984 Congress enacted scores of mandatory minimum sentences. ${ }^{48}$ Neither Congress nor the Commission has demonstrated discipline or restraint in the allocation of punishment; until they do, there will be predictable pressure to escalate microlevel sanctions so that the guidelines cannot work as written. The Commission disregarded the Sen-

47. The United States Parole commission strongly advocated this approach. In 1980, I wrote a letter proposing the model to Representative Robert F. Drinan, who chaired the House Subcommittee on Criminal Justice. He wrote back a detailed letter with comments and questions on the proposal. It was rejected or otherwise died at some point during the legislative process.

48. See U.S. SENTENCING COMM'N, SPECIAL REPORT TO THE CONGRESS: MANDATORY MINIMUM PENALTIES IN THE Federal CRIMINAL JUSTICE System 7-13 (1991). 
tencing Reform Act's directive on capacity constraints, but Congress did not hold it accountable for that decision.

\section{Revision via Departures}

Several thoughtful observers and practitioners favor using departures to revise the guidelines. ${ }^{49}$ Advocates argue that for this system of revision to work, departures should be encouraged, and high departure rates should be tolerated during the early years of guideline implementation. Once the guideline norms shift, then departure rates should be reduced. ${ }^{50}$ They suggest that departures could shift guideline norms in two ways: by prompting the Commission to revise the guidelines or by encouraging emergence of case law as a separate source of judicial authority.

\section{Revision by the Commission in Response to Departures}

The Commission, some argue, could analyze departures in terms of frequency, direction, reasons, and types of cases, and then use these findings as a foundation for guideline revisions. Departures would serve as a form of communication between the Commission and the bench. In a sense, judges' departures would constitute "votes" for amending Commission policies.

Of course, it is not clear that the U.S. Sentencing Commission would respond to increased departures by amending its guidelines in ways preferred by judges. In the past, it has sometimes taken the opposite tack, foreclosing future departures for the very reasons cited by judges.

\section{Stimulating Case Law}

A common law of sentencing could emerge from contested departures. This common law would stand alongside the guidelines as a separate source of judicial authority, whether or not the Commission decided to amend its guidelines.

\section{The Drawbacks of Departures}

Both proposals are seriously flawed. They would undermine-and perhaps eliminate-the guidelines' ability to reduce sentencing disparity. Understanding the effects of these proposals requires an examination of how guidelines are supposed to reduce disparity.

49. See, e.g., Gerald B. Tjoflat, The Untapped Potential for Judicial Discretion Under the Federal Sentencing Guidelines: Advice for Counsel, FED. PROBATION, Dec. 1991, at 4, 5.

50. See Freed, supra note 4, at 1750-51. 
Guidelines sort offenders and offenses into comparable categories and scale the severity of punishment presumed appropriate for each category. Normatively acceptable sorting criteria and a consistently applied penalty structure will greatly reduce disparity. All cases differ, but not in ways that are relevant under sentencing guidelines. For the great majority of cases, an appropriate sentence can be determined with a small number of important criteria. Thus, the guidelines themselves are the primary means to reduce disparity.

Departures play a secondary and very limited role in reducing disparity. The primary reason for departures is to achieve more proportional punishments for the small number of exceptional cases that do not fit into the general norms embodied in the guidelines and therefore require sentences outside the usual range. If judges are prodigal in their use of departures, they will increase disparity by departing when it is not warranted, by departing in the wrong directions, or by departing by excessive amounts. Departures were never intended to be a mechanism for fundamentally revising sentencing guidelines. Other mechanisms, such as public hearings at which constituents can propose or debate changes, are the more proper way to achieve basic policy reform.

Of course, a sentencing commission could consider departure patterns when it fine-tunes its guidelines. In Minnesota, for example, the original guidelines called for probation for every offender convicted of unauthorized use of a motor vehicle (UUMV), ${ }^{51}$ regardless of the length of his or her prior record. ${ }^{52}$ While few offenders convicted of UUMV had very long criminal records, Minnesota judges departed to imprison almost all of them. Recognizing this, the commission amended its guideline by making short prison terms presumptive for these offenders. ${ }^{53}$

In conclusion, a high departure rate may permanently eliminate any chance of reducing disparity. Once accustomed to the flexibility accorded by frequent departures, there is no guarantee that judges will later accede to a lower rate of deviation from the guidelines.

Case law as a means of achieving fundamental guideline revision is similarly problematic. Case law develops slowly, and the problems caused by the

51. MiNN. STAT. ANN. $\S 609.52$ subd. 2(17) (West Supp. 1992).

52. The commission argued that UUMV, if properly charged, should apply only to joyriding offenses. If an offender stole a car with intent to deprive the owner of it permanently, the offense should be charged as a theft, a more serious crime for which the guidelines recommended prison for offenders with moderate prior records. See PARENT, supra note 42 , at 92 \& n.5.

53. See MINNESOTA SENTENCING GuIDELINES, supra note 5, at 416 . In other circumstances, a commission might resist changing a guideline even in the face of high departure rates. In Minnesota, seconddegree assault involves threatening someone with a dangerous weapon. MNN. STAT. ANN. \$ 609.222 (West Supp. 1992). Minnesota's legislature created a separate sentencing enhancement (mandatory imprisonment for one year on the first offense) for all crimes committed with a dangerous weapon, to be imposed upon recommendation of the prosecutor. Id. $\S 609.11$ subds. 4, 6-7 (West $1987 \&$ Supp. 1992). The commission took the position that a second-degree assault conviction should be punished by a one-year prison term, refiecting the mandatory minimum for crimes committed with a dangerous weapon. Although judges departed in over $60 \%$ of the second-degree assault convictions involving first offenders, the commission stood on principle and maintained its policy. 
federal sentencing guidelines may require more immediate solutions. The flow of information in appellate litigation is more narrow and more filtered than in an overt policymaking process, such as in a legislative body or an executive agency with rulemaking authority. A litigant can raise only the issues relevant to the claim he or she is presenting. While relevance is a flexible criterion, few litigants are likely to challenge the guidelines in global terms. Most will challenge only one or two narrow points about the guidelines' rules, interpretations, or applications. Appellate judges are not likely to inquire how a litigant's narrow challenge, if upheld, will affect the overall structure or coherence of the guidelines. Litigants raise issues on a piecemeal basis, yet guideline policies are interrelated, and a seemingly minor change in one element imposed by a court decision could have serious effects on other parts of the guidelines that were not at issue in the litigation.

Finally, there is no guarantee that the doctrines emerging through case law will improve the operation of the guidelines. They could just as easily make matters worse. Appellate review may be well suited to chipping away at minor problems in a fundamentally sound public policy, but it is not a good way to draft fundamental policy changes.

In summary, if the guidelines' norms need to be changed, they should be changed by political means, beginning with the Commission's own internal process for revision and, if that proves unfruitful, by moving to the congressional arena. Rampant departures are more apt to ruin the guidelines completely than to achieve even minimally effective reform.

Opponents of determinate sentencing have warned of the perils of exposing microlevel sentencing policy to direct political influence. Indeterminate sentences (whatever its defects) tended to insulate case level sentencing from the passions and vagaries of the political process and seemed to mitigate harsh penalties. ${ }^{54}$ With respect to the federal system, they may have been right. If Minnesota's legislature passes a sentencing law that will cost forty million dollars for new prison construction, its members must take the money from education, health care, libraries, or other important social programs. If Congress passes mandatory minimums that add hundreds of millions to the cost of federal prisons, they merely add another drop to an ocean of red ink. Unconstrained by a sense of discipline, Congress and the Commission have crafted a microlevel sentencing policy that reflects the nation's fears, not its hopes or even its best interests. Nonetheless, the experience may have one redeeming value: It can teach important lessons to state policymakers considering sentencing reform options, if they will but listen and learn.

54. Commentators have noted that harsh sentences, imposed by political processes, may lead to higher avoidance rates. As Andrew von Hirsch said: "Writers of sentencing guidelines need, therefore, to be sensitive to the link between severity and incentive to avoid [harsh sentences]. As the level of sanctions rises, the difficulties of applying them evenhandedly also increase." Andrew von Hirsch, Federal Sentencing Guidelines: Do They Provide Principled Guidance?, 27 AM. CRM. L. REV. 367, 375 (1989). 
